University of St. Thomas, Minnesota

UST Research Online

Philosophy Faculty Publications

Philosophy

2008

Evolution, providence, and Gouldian contingency

Michael W. Rota

University of St. Thomas, Minnesota, mwrota@stthomas.edu

Follow this and additional works at: https://ir.stthomas.edu/cas_phil_pub

Part of the Ecology and Evolutionary Biology Commons, Philosophy Commons, and the Religious

Thought, Theology and Philosophy of Religion Commons

This Article is brought to you for free and open access by the Philosophy at UST Research Online. It has been accepted for inclusion in Philosophy Faculty Publications by an authorized administrator of UST Research Online. For more information, please contact asle4660@stthomas.edu. 
Religious Studies 44, 393-412 ㄷ 2008 Cambridge University Press doi:10.1017/S0034412508009499 Printed in the United Kingdom

\title{
Evolution, providence, and Gouldian contingency
}

\author{
MICHAEL ROTA \\ Department of Philosophy, 241 JRC, University of St Thomas, 2115 Summit Ave, St Paul, \\ MN 55105
}

\begin{abstract}
Stephen Jay Gould and others have argued that what we know about evolution implies that human beings are a 'cosmic accident'. In this paper I examine an argument for Gould's view and then attempt to show that it fails. Contrary to the claims of Gould, Daniel Dennett, and others, it is a mistake to think that what we have learned from evolutionary biology somehow shows that human beings are mere accidents of natural history. Nor does what we know about the contingency of evolution give us good reason to reject the view that human beings came to be according to a divine providential plan.
\end{abstract}

According to traditional Christian notions of divine providence, the ultimate explanation of the existence of human beings has to do with the purposes of God: God wanted us to exist, in order that we might freely choose to enter into personal communion with Him and other persons. We are the result of the purpose and plan of a supernatural being. Is this view - the view that human beings are the intended product of a divine plan - compatible with the deliverances of contemporary evolutionary biology?

It might seem that the answer is 'No'. According to the late paleontologist Stephen Jay Gould, human beings are a 'momentary cosmic accident', 1 even if a 'glorious accident'. ${ }^{2}$ Gould supports this claim by arguing for the radical contingency of the human species. Summing up his view, he writes: 'Wind back the tape of life to the early days of the Burgess Shale; let it play again from an identical starting point, and the chance becomes vanishingly small that anything like human intelligence would grace the replay.' ${ }^{3}$

Gould is not alone in holding that what we know about evolution ${ }^{4}$ provides strong evidence that human beings are not the result of any divine purpose or plan. In the opinion of philosopher Daniel Dennett, a key feature of Darwinism is the idea that evolution is 'an algorithmic process', which implies that the underlying process of evolution 'consists of nothing but a set of individually mindless 
steps succeeding each other without the help of any intelligent supervision; they are "automatic" by definition: the workings of an automaton'. ${ }^{5}$ The evolutionary process, Dennett contends, is mindless and mechanical, nor was it itself designed. Noting the dazzling complexity of the biological world, Dennett asks: 'Can [the biosphere] really be the outcome of nothing but a cascade of algorithmic processes feeding on chance? And if so, who designed that cascade?' His answer: 'Nobody. It is itself the product of a blind, algorithmic process. ${ }^{6}$ And again, 'Evolution is not a process that was designed to produce us. ${ }^{7}$ On Dennett's view, a proper understanding of evolution rules out the thesis that humans were intentionally produced in accordance with a divine plan. ${ }^{8}$

In this paper I argue that Gould and Dennett are mistaken. In the first section I develop Gould's ideas about the contingency of the evolutionary process in order to construct an argument that human beings are not an intended product of some divine plan. In the second I attempt to show that this argument fails to establish its conclusion.

\section{The Gouldian contingency argument}

If there were a God, it might be said, He either could not or would not have intended to use an evolutionary process to bring about the existence of humans. Two reasons might support this objection, one concerning the problem of evil, the other concerning the contingency of the evolutionary process. It might be thought, first, that the evolutionary process involves too much violence and suffering to be a suitable method for God to employ. ${ }^{9}$ Second, it could be claimed that the evolutionary process is too contingent to be the sort of process that God could have used to bring about the existence of humans. In this paper I examine this second claim.

Consider again Gould's view that if we were to wind back 'the tape of life to the early days of the Burgess Shale', and let it play again from the same starting point, then the chance that 'anything like human intelligence would grace the replay' would be 'vanishingly small'.$^{10}$ Suppose this is true, or suppose that at the time when life first appeared on Earth, the objective probability was exceedingly small that the evolutionary process would someday yield the generation of human beings. Then the claim that God planned to produce humans via the evolutionary process would seem quite implausible. It would be similar to the claim of a lottery winner that he had planned to win the lottery. On this view the coming to be of humans via an evolutionary process could not be part of a divine plan, because it could not have been expected or reliably predicted in advance.

We can make this argument rigorous as follows:

(1) The objective probability, at the time of the appearance of life on Earth, that human beings would someday be produced by 
an evolutionary process (of the sort we have evidence of) is extremely low. ${ }^{11}$

(2) If the objective probability is extremely low that a particular outcome $\mathrm{O}$ would someday be produced by a process $\mathrm{P}$, then a rational agent intending to bring about $\mathrm{O}$ could not (or at least would not, if other alternatives were available) plan to bring about $\mathrm{O}$ by means of $\mathrm{P}$.

Thus,

(3) A rational agent intending to bring about the existence of human beings could not (or at least would not, if other alternatives were available) plan to bring about the existence of human beings by means of an evolutionary process (of the sort we have evidence of).

God, of course, is supposed to be the supremely rational agent. And being omnipotent, God would have had other alternatives available. So,

(4) If God had intended to bring about the existence of human beings, then God would not have planned to bring about the existence of human beings by means of an evolutionary process (of the sort we have evidence of).

In other words, if it were the case that the existence of human beings was intended by God, then God would not have used an evolutionary process (of the sort we have evidence of). So if the existence of human beings had been part of some divine plan, then it would not be the case that human beings came to be via an evolutionary process. But human beings have come to be via an evolutionary process. Thus, it can't very well be the case that the existence of human beings was part of a divine plan. And this entails that:

(5) Human beings are not the product of a divine plan.

\section{Response to the contingency argument}

This line of reasoning faces at least two major difficulties, both concerning the crucial empirical premise of the argument, proposition (1). In what follows I shall try to show that the Gouldian contingency argument is unsuccessful in establishing its conclusion. What we know about the contingency of evolution does not give us good reason to affirm that human beings are a mere accident, nor does it give us good reason to reject the view that human beings are the product of a divine plan.

\section{Questioning Gouldian contingency}

Premise (1) in the contingency argument makes a claim about human beings. Suppose, for the sake of argument, that we grant the truth of (1) as applied 
to the biological species homo sapiens, i.e. suppose we grant that it was extremely unlikely for evolution to yield the bipedal, relatively hairless, five-fingered beings that we are. The probability still might have been quite high that some species of rational animal would some day be produced by the evolutionary process. And perhaps what was efficaciously intended by God was not the emergence of the biological species homo sapiens, but simply some species of rational animal or another. Such a species could be very different than homo sapiens in terms of physical features, but would be similar in possessing the capacity for abstract thought, free choice, and an understanding of morality.

If a theist asserts that God intended for human beings to come to be via an evolutionary process, that theist might mean either of two things. She might be committed to the view that God intended that the particular species homo sapiens emerge from an evolutionary process. But she might be committed only to the view that God intended that some species of rational animal emerge from the evolutionary process. Indeed, there is a long tradition in philosophy of defining a human being as a rational animal. Consider also the biblical claim that human beings are made in the image of God. ${ }^{12}$ In virtue of what, exactly, are humans made in the image of God? Not in virtue of being bipedal, relatively hairless, and having five fingers on each hand. Human beings are made in the image of God in virtue of their rationality, in virtue of their possession of intellect and free will. Such is one traditional position, anyway. The influential eighthcentury theologian John of Damascus taught that human beings are 'in the image of God' in virtue of intellect and free will. ${ }^{13}$ For Aquinas, too, human beings are said to be 'in the image of God' on account of their intellectual nature. ${ }^{14}$ Aquinas expressly denies that the image of God is in human beings with respect to the body. ${ }^{15}$

It follows that rational animals with physical characteristics different from those of homo sapiens would also be made in the image of God (in virtue of being rational). And it could be that God's intention was simply to ensure the emergence of some embodied being made in God's image, i.e. some rational animal or another. Call this the broad view of God's providential plan, as opposed to the narrow view which holds that God's intention was to ensure the emergence of homo sapiens.

The Gouldian contingency argument, as I've stated it, is ambiguous about the meaning of 'human beings'. The conclusion could be taken to mean either,

(5a) Rational animals are not the product of a divine plan.

Or,

(5b) The biological species homo sapiens is not the product of a divine plan. 
Let's take each possibility in turn. In order for the argument to successfully establish (5a), the first premise would have to be changed to:

(1a) The objective probability, at the time of the appearance of life on Earth, that some species of rational animal would someday be produced by an evolutionary process (of the sort we have evidence of) is extremely low. ${ }^{16}$

Call the argument that results from making similar changes to the other premises the broad version of the Gouldian contingency argument. ${ }^{17}$ Note that this argument cannot be successful unless (1a) is on solid ground. But is it?

According to the now well-known work of Simon Conway Morris, it is not. ${ }^{18}$ On the contrary, thinks Conway Morris, the empirical evidence is against (1a) rather than for it:

[I]t is now widely thought that the history of life is little more than a contingent muddle punctuated by disastrous mass extinctions that in spelling the doom of one group so open the doors of opportunity to some other mob of lucky-chancers. ... Rerun the tape of the history of life, as S. J. Gould would have us believe, and the end result will be an utterly different biosphere. Most notably there will be nothing remotely like a human ... . Yet, what we know of evolution suggests the exact reverse: convergence is ubiquitous and the constraints of life make the emergence of the various biological properties [e.g. intelligence] very probable, if not inevitable. ${ }^{19}$

As Conway Morris puts it in another place, 'something like ourselves is an evolutionary inevitability'. ${ }^{20}$

The key to Conway Morris's argument has to do with evolutionary convergence, "the recurrent tendency of biological organization to arrive at the same "solution" to a particular "need".'. ${ }^{21}$ Natural selection has a way of repeatedly arriving at functionally similar features or faculties, even when beginning from very different starting points. This is so especially when there are strong constraints on what sort of feature or faculty could possibly be successful in 'solving' some adaptive 'problem'. For example, there may well be a limited number of ways in which eyes can possibly work, ${ }^{22}$ and upon analysis it appears that the camera-eyes of vertebrates are better than the compound eyes of most insects, at least when it comes to their ability to improve the fitness of an organism with some level of sentience. ${ }^{23}$ It's therefore not surprising that the camera-eye has evolved independently at least six different times ${ }^{24}$ (in the vertebrates, the advanced cephalopods (e.g. squid and octopus), multiple times in the gastropods (snails), and in some marine annelids (close relatives to the earthworms). ${ }^{25}$ It is as if natural selection explores adaptive space and repeatedly hits upon highly successful outcomes.

Conway Morris gives numerous examples of convergence, including the independent evolution of agriculture (among ants and humans), large brains (among primates and the toothed whales), intelligence (in various levels among numerous 
species), tool-use (in crows, primates, dolphins, and possibly even wasps), and the cultural transmission of behaviours (among more than one type of hominoid, whales, and possibly some birds).$^{26}$ Given these and other considerations, he argues that it was highly probable that something like human intelligence would eventually emerge in the course of evolution on Earth.

Now, if Conway Morris is right, (1a) is false, and the broad version of the Gouldian contingency argument fails to establish (5a). At this point a defender of Gould might note that some biologists have criticized Conway Morris's position, and might object that because Conway Morris's case has not been proven, my use of his work to rebut the broad version of the Gouldian contingency argument is unsuccessful. But here there would be a confusion about the burden of proof. We do not need to know that Conway Morris is correct to see that his work undercuts the broad Gouldian argument. Whether or not Conway Morris is in the end correct, his work shows that the current state of scientific evidence is such that (1a) is by no means a solidly established scientific claim. Work on evolutionary convergence casts serious doubt on (1a), and this means that the broad version of the Gouldian contingency argument has a dubious premise. Gould's argument would only be convincing if (1a) were solidly established, which it is not. The broad version of the Gouldian contingency argument therefore does not succeed in giving us a good reason to accept (5a).

Things don't fare much better for (5b). In order for the Gouldian contingency argument to establish (5b), we would (at the least) need to replace the mention of human beings in the argument with mention of homo sapiens (or in some other way specify that when 'human beings' is used in the argument, it is to be understood in such a way that human beings are essentially members of the species homo sapiens). Call the argument resulting from such replacements the narrow version of the Gouldian contingency argument. Even if that argument's first two premises (call them (1b) and (2b)) are granted, the narrow argument is still unsuccessful, because (5b) does not follow from those premises.

Suppose it is granted that God did not intend that the species homo sapiens rather than some other species of rational animal emerge from the evolutionary process. That is, suppose the scope of God's intention was such that the statement 'God precisely intended that the particular species homo sapiens emerge from the evolutionary process' is false. It does not follow that:

(5b) The biological species homo sapiens is not the product of a divine plan.

To see this, consider an analogy. Suppose the board of directors of the Ford Motor Company wants Ford to produce a new car, in order to fill the emerging niche in the market for fuel-efficient gas-electric hybrids. The board instructs Ford's CEO to produce a vehicle under that description. Two years later, the CEO returns to the board with the announcement that Ford has just rolled out their 
new hybrid, a four-door sedan which gets forty-five miles to the gallon. Now, it was not within the scope of the board's intention that the new car be a four-door sedan rather than a two-door sport coupé, a station-wagon, or something else. So the statement that 'The board precisely intended that the particular type a four-door sedan hybrid emerge from the engineering and production process' is false. Nevertheless, there is a sense in which it is true that 'Ford's production of their new four-door sedan was intended by the board of directors'. And it is even more clearly true that 'Ford's new four-door sedan is the product of a plan initiated by the board of directors.'

Analogously, suppose God intends that the evolutionary process give rise to some species of rational animal or another, but does not specifically intend that that species be homo sapiens. If, as it turns out, homo sapiens does indeed arise, it is still true to say that 'Homo sapiens is the product of a plan initiated by God.' The further proposition that the very same plan of God might have resulted in some other species of rational animal does not imply that homo sapiens is not the product of a divine plan, any more than the proposition that the very same plan of the board of directors might have resulted in Ford's producing some other type of fuel-efficient vehicle implies that Ford's new car was not the product of a plan initiated by the board of directors. So (5b) does not follow from its premises. (1b) could be true, but if (1a) were false, then (5b) could well be false.

The ambiguity in the Gouldian contingency argument relating to the meaning of 'human beings' can be resolved in either of two ways. If it is resolved in the first way (by defining human beings as rational animals), then the first premise is dubious. If it is resolved in the second way (by defining human beings as members of the species homo sapiens), then the argument is invalid.

\section{The chess-master view of God's providence over evolution}

Premise (1) of the Gouldian contingency argument has a second problem, even if we take it in the narrow sense of:

(1b) The objective probability, at the time of the appearance of life on Earth, that the biological species homo sapiens would someday be produced by an evolutionary process (of the sort we have evidence of) is extremely low.

Towards showing this, let me distinguish between: (i) epistemic indeterminacy, and (ii) objective or ontological indeterminacy. To say that the outcome of some process is epistemically indeterministic is to say that the outcome cannot be predicted in advance. What is and what is not epistemically indeterministic will be agent-relative: what is unpredictable for one agent might be predictable for another. Ontological indeterminacy has to do not with an agent's knowledge about some process, but with the nature of the process itself. 
In this sense of 'indeterminacy', an indeterministically produced event is an event that is caused but not guaranteed by its causes.

Suppose that some event $\mathrm{E}$ is caused by some number of causal factors. And suppose we ask, 'Given that all those causal factors occurred, and given that the causal laws are what they actually are, and given that everything else causally antecedent to E happened just as it actually happened, did E have to occur?' Holding fixed the causally relevant antecedents of $\mathrm{E}$, was the occurrence of $\mathrm{E}$ metaphysically necessary? If the answer is 'Yes', then $\mathrm{E}$ is a deterministically produced event. If the answer is 'No', then $\mathrm{E}$ is an indeterministically produced event.

Now, the Gouldian contingency argument depends on the thesis that there is real ontological indeterminacy in the physical world. In a deterministic world, the way the evolutionary process in fact turned out is the way that it had to turn out. So if there is no ontological indeterminacy, (1), (1a), and (1b) are all false. The contingency argument therefore requires the assumption that there is real, objective indeterminacy in the physical world. Also required is the assumption that this indeterminacy can percolate up (say, from the quantum level) in such a way as to have an effect on the course of macro-level events.

Suppose, as seems likely, that these assumptions are correct. Given the presence of indeterministic processes in the course of evolutionary history, there is a real sense in which history could have taken different paths. But then it seems that God could not have ensured that history actually took the particular path it did (a path involving homo sapiens). Given that God creates things with the capacity to act indeterministically, and given that God allows them to be in situations in which they can exercise that capacity, God cannot ensure a particular evolutionary outcome.

Or so it might seem, depending on what we mean by a 'particular' evolutionary outcome. It is true that if God indeed creates things with the capacity to act indeterministically, and allows them to be in situations in which they can exercise that capacity, then God cannot ensure, just by willing it, that history takes precisely a given individual path. ${ }^{27}$ It is within God's power, however, to ensure particular types of outcomes, in virtue of His ability to interact causally with the world. If the course of evolution is proceeding in a way unacceptable to God, it is open to Him to nudge it in a direction He wishes. ${ }^{28}$

Suppose God has this specific plan for the evolutionary process: He wants the species homo sapiens to emerge within 5 billion years of the Earth's formation. Given divine omniscience, for any given time God will know the likelihood at that time that this goal will be attained if He allows events to unfold according to the ordinary course of nature. He will also know the likelihood of this goal being attained given various causal contributions He could make which would involve special divine action. ${ }^{29}$ Given divine omnipotence, it is within God's power to affect the course of evolution in a number of different ways, and at an unimaginable number of points, and so to bring about His goal in one way or 
another. If God exists, He could ensure that homo sapiens emerges from the evolutionary process in virtue of His willingness and ability to steer evolution toward that end if need be.

Compare Peter Geach's discussion of God's control over the future in a world where human beings have genuine freedom:

If man is a child of God with power over his own works then we must not view the world as

A Checker-board of nights and days

Where Destiny with men for pieces plays.

Rather, God and man alike play in the great game. But God is the supreme Grand Master who has everything under his control. Some of the players are consciously helping his plan, others are trying to hinder it; whatever the finite players do, God's plan will be executed; though various lines of God's play will answer to various moves of the finite players. God cannot be surprised or thwarted or cheated or disappointed. God, like some grand master of chess, can carry out his plan even if he has announced it beforehand.

'On that square,' says the Grand Master, 'I will promote my pawn to Queen and deliver checkmate to my adversary': and it is even so. ${ }^{30}$

Geach's contention is that, despite the fact that some of what happens is genuinely up to us, God ensures certain outcomes in virtue of His great power and knowledge. I suggest that we adapt this view from Geach's context (in which it is the indeterminacy involved in human freedom that is at issue) to the context of contingency in evolution (in which microphysical indeterminacy affecting the course of evolution is at issue). My contention is that God has the ability to ensure even the quite specific result that homo sapiens emerges from the evolutionary process, in virtue of His willingness and ability to steer evolution toward that end if need be. Suppose further that God not only has this ability, but in fact actually intends to use it. That is, suppose that God has intended to ensure the emergence of homo sapiens from the evolutionary process, via special divine action if necessary. For lack of a better name, call this the chess-master view of God's providence over evolution. ${ }^{31,32}$ If tenable, this view defuses the Gouldian contingency argument, since if it is correct, (1), (1a), and (1b) are all false.

The position I'm advancing is not Intelligent Design theory (ID). According to ID, we now possess scientific evidence that certain features of organisms did not come to be via an evolutionary process, but were directly constructed or designed by some intelligent agent(s). I am not making this claim, nor am I claiming that we have scientific evidence that God has intervened in the evolutionary process.

What I am asserting is this: for all we know, God might have intended homo sapiens to some day be produced by an evolutionary process, and might have been prepared to ensure this outcome via special divine action. Again, I am not asserting that we have scientific evidence that:

(A) God intended homo sapiens to someday be produced by an evolutionary process, and was prepared to ensure this outcome via special divine action. 
I am instead merely claiming that (A) might be true. Nothing we know gives us good reason to think (A) is false. Since (A) implies the falsity of (1a) and (1b), it follows from the claim that (A) might be true that (1a) and (1b) might be false. But then the Gouldian contingency argument contains a dubious premise. So if the chess-master view is tenable, Gould's argument fails.

Is the chess-master view tenable? There is no question that an omnipotent, omniscient God could guide the course of evolution so as to ensure the emergence of homo sapiens, but would He? Has He? Potential objections to the chessmaster view involve: (a) claims that we have scientific evidence that God has not acted in this way (guiding evolution in one direction rather than another), or (b) worries that it is somehow inappropriate (scientifically or theologically) to think that God might intend to do so. ${ }^{33}$ In what follows my intention is to falsify claims that we have good reason to think God has not guided (or would not have guided) evolution in any way.

A first possible objection asserts that we have good scientific evidence against the claim that God has guided evolution. (Precisely this assertion was made by a biologist from the floor during the recent Terry Conference at Yale. ${ }^{34}$ ) The putative evidence concerns the spontaneity of mutations, and the fact that beneficial mutations are not statistically favoured over non-beneficial mutations. ${ }^{35}$ So, for example, when certain bacteria are placed in an environment in which a particular mutation would be beneficial, it is not the case that the mutations which actually occur are statistically biased in favour of that beneficial mutation.

It's not hard to see that these facts would count as evidence against the claim that God has guided evolution only if the truth of that claim ${ }^{36}$ would lead us to expect that God would act specially upon the particular organisms being studied. But there is no reason to suppose that. Suppose that God has guided evolution by means of special divine action at some number of points in the history of evolution. This does not imply that God does so at all times and for all organisms, or that God does so frequently, or even that God does so more than in an exceedingly minute percentage of all mutations or similarly relevant events. Much less does it suggest that God would be interested in tinkering with the organisms in Luria and Delbruck's petri dish. In general, experimental evidence regarding the ordinary course of nature does not count as good evidence against the claim that God occasionally causes some events to depart from the ordinary course of nature.

What sort of evidence could plausibly be regarded as good evidence against the claim that God has guided the course of evolution? An initial suggestion: suppose we had complete knowledge of all the natural (i.e. created, non-divine) causes of every mutation that ever occurred (and of all environmental changes, events involving random genetic drift, and any other events similarly relevant to the course evolution takes.) Further suppose that we could see that all such mutations and other events had proceeded from their natural causes according to the ordinary 
laws of nature. Wouldn't that count as good evidence that God was not guiding the course of evolution?

Somewhat surprisingly, it wouldn't. Let S be the total set of mutations and other similarly relevant events, and let $\mathrm{C}$ be the set containing every natural cause of every event in S. Earlier, we defined an indeterministically produced event as an event that is caused but not guaranteed by its causes. Now consider a distinct, though related, notion: let a naturally indeterministically produced event be an event that is caused, but that is not guaranteed by its creaturely causes. A naturally indeterminisitically produced event might or might not be an indeterministically produced event simpliciter, depending on whether God determines its occurrence or leaves both its occurrence and non-occurrence open.

Now, either there are some naturally indeterministically produced events in S or there are none. If there are none, then the grounds for believing (1) are removed and the Gouldian contingency argument fails regardless of the tenability of the chess-master view. ${ }^{37}$ So suppose there are. Take one such event, C1. Ex hypothesi, we know all the natural causes of $\mathrm{C} 1$, and can see that $\mathrm{Cl}^{\prime}$ s following from its causes is consistent with the ordinary course of nature. Given that $\mathrm{C} 1$ is a naturally indeterministically produced event, however, it remains the case that the natural causes of $\mathrm{C}_{1}$ did not guarantee that it occurred. It might have been the case, consistent with the laws of nature, that all the natural causes of $\mathrm{C} 1$ occurred but $\mathrm{C} 1$ not have occurred. Since we cannot rule out that God exerted a causal influence to bring about $\mathrm{C} 1$ rather than some other nomologically possible event, we cannot rule out that God was active in guiding the course of history towards C1. More generally, in a world that appears indeterministic to us, we will never be able to say that God is not acting specially to guide the outcomes of indeterministic processes in one direction rather than another. So even if we could some day obtain the utterly unrealistic level of knowledge about the causal history of evolution described above, we still would not be in a position to say that we had good evidence that God did not guide evolution.

It's worth noting that God might not need to do anything dramatic to guide the course of evolution. In fact, it seems entirely possible that God could direct the course of evolution in a way so subtle as to be de facto undetectable to empirical science.

Suppose, as has been suggested, that 'genetic mutation can be induced by a variety of quantum mechanical transitions' ${ }^{38}$ Then God could bring about the occurrence of certain mutations merely by making some quantum events come out one way rather than another. ${ }^{39}$ It strains credibility to think that we will ever be in a position to determine whether, say, a given quantum event occurring millions of years ago came about according to the ordinary course of nature or via special divine action. If God occasionally selects one from among many physically possible outcomes of certain quantum events, there is no reason to think 
that we would ever be able to detect this empirically. Thus, it seems possible that God could direct the course of evolution in a way de facto undetectable to us.

Even if we do not have experimental evidence against the claim that God has guided evolution, we do have, according to a second objection, a different scientific reason to reject the chess-master view of God's providence: our ability to do science well will be compromised if we hold that God has guided (or was prepared to guide) the course of evolution via special divine action. ${ }^{40}$ According to evolutionary biologist Michael R. Rose,

If an omnipotent creature [sic, read 'creator'] can intervene in events in the known universe, then there is no reason to suppose that any law of science will necessarily remain constant. Indeed, to the extent to which the processes under scientific study are subject to divine intervention, they become unsuited to further scientific study at all. ${ }^{41}$

In a similar vein, Nobel-Prize-winning physicist Steven Weinberg writes, '[T]he only way that any sort of science can proceed is to assume that there is no divine intervention and to see how far one can get with this assumption. ${ }^{42}$

On this view, a belief that God has guided evolution (or was prepared to guide evolution) is anti-scientific, because God's doing so would require that God occasionally bring about effects outside of the ordinary course of nature, and if we believe God may occasionally bring about effects outside the ordinary course of nature, our ability to do science well will be compromised. The crucial claim here is

(6) If we believe God may occasionally bring about effects outside the ordinary course of nature, our ability to do science well will be compromised.

The worry is that a belief in occasional divine intervention will undercut one's motivation or ability to engage in at least some of the practices which facilitate scientific discovery. Rose provides an example to motivate this line of thought:

Let us suppose that a particular theory of superconductivity requires that a given alloy have a particular electrical resistance of $10 \mathrm{~K}$. If that resistance is being measured in a laboratory at 3:15 pm on a Tuesday and the result is not what was expected by the theory, then a creationist scientist could say, simply, that God must have intervened to change the alloy so as to get the observed result. The alternative, which a noncreationist would be forced to embrace, is to admit that the original theory is wrong. ... This is the essential clash between science and nonscience. With the latter, there is always room to move about to avoid accepting any evidence indicating that you, or your favored ideas, are wrong. ${ }^{43}$

Rose's example suggests the following argument for (6). Where a theory T makes a prediction $\mathrm{P}$, and we observe $\sim \mathrm{P}$,

(7) If we believe God may occasionally bring about effects outside the ordinary course of nature, then we are able to say, 'God must have intervened to bring about $\sim \mathrm{P}$.' 
(8) If we are able to say, 'God must have intervened to bring about $\sim \mathrm{P}$ ', then we will have a good reason to ignore the evidence against $\mathrm{T}$ that our observation provides.

(9) If we have a good reason to ignore the evidence against $\mathrm{T}$ that our observation provides, then our ability to do science well will be compromised.

Hence, (6).

To evaluate this argument, consider (8). Suppose that John is a staunch advocate of theory T, who also happens to believe that there is no God (or anything like God), and who believes that nature as a whole is a closed causal system. Suppose John himself does the experiment to test theory T. Confronted with the observation that $\sim \mathrm{P}$, John is able to say, 'A lab assistant from one of my rivals must have tampered with my experiment, to bring about $\sim$ P.' But that of course does not mean that it is reasonable for John to say this, or to give it any credence. From the mere fact that John is able to say that a rival laboratory assistant must have intervened, it does not follow that John has a good reason to ignore the evidence against $\mathrm{T}$ that his observation of $\sim \mathrm{P}$ provides. Similarly, from the fact that $\mathrm{S}$, a believer in occasional divine intervention, is able to say that 'God must have

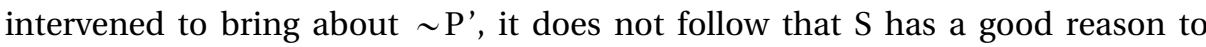
ignore the evidence against $\mathrm{T}$. Thus, (8) is false. What is really at issue is whether $S$ 's belief in (the possibility of) occasional divine intervention provides a good reason to think 'God must have intervened to bring about $\sim$ P.'

A defender of Rose's position might therefore want to modify the argument to get:

$\left(7^{*}\right)$ If we believe God may occasionally bring about effects outside the ordinary course of nature, then we have a good reason to believe that God must have intervened to bring about $\sim \mathrm{P}$.

$\left(^{*}\right)$ If we have a good reason to believe that God must have intervened to bring about $\sim \mathrm{P}$, then we will have a good reason to ignore the evidence against $\mathrm{T}$ that our observation provides.

(9) If we have a good reason to ignore the evidence against $\mathrm{T}$ that our observation provides, then our ability to do science well will be compromised.

Hence, (6).

$\left(8^{*}\right)$ may be acceptable, but now $\left(7^{*}\right)$ is false. The belief that God may occasionally bring about effects outside the ordinary course of nature does not provide a good reason to believe that God must have intervened in this particular instance. Indeed, the belief in the possibility of occasional divine intervention provides practically no warrant at all for any claim of the form 'God has intervened at this particular point in space and time'. An analogy: imagine that John believes that, in the past, it has very occasionally occurred that one scientist's 
experiment has been tampered with by someone else. That belief by no means gives John a good reason to believe that someone must have tampered with his experiment to bring about $\sim \mathrm{P}$. The case is the same for the believer in occasional divine intervention.

Perhaps we can find a better argument for (6) based on Rose's assertion that, 'If an omnipotent creature [sic, read "creator"] can intervene in events in the known universe, then there is no reason to suppose that any law of science will necessarily remain constant. ${ }^{\prime 4}$ This assertion is equivalent to

(10) If an omnipotent God can intervene in events in the known universe, then there is no reason to suppose that any law of science will necessarily remain constant.

This seems true, given that what is meant is that there is no reason to believe that, necessarily, every law is exceptionless throughout space and time. That is, I think we should grant (10) if we take it as meaning:

(10a) If an omnipotent God can intervene in events in the known universe, then there is no reason to believe that 'Necessarily, ${ }^{45}$ no law of science ever admits of an exception'.

One could, however, believe that an omnipotent God can intervene in events in the known universe, and still have a reason to believe that, for a given law of science L, 'L holds almost all of the time'.

Suppose, for instance, that Ken believes that an omnipotent God can intervene in the course of natural events. Ken, being knowledgeable in the ways of science, will be aware of the considerable inductive evidence that the laws of science have held almost all of the time in the past. ${ }^{46}$ Being rational, he will have a belief in the uniformity of nature, i.e. the belief that the regularity we have observed in the past will continue in the future. He will therefore have a good reason to think that the laws of science will hold almost all of the time. Ken may think that things can (and even do) go differently on rare occasions, but that does not constitute a defeater for his belief that the laws hold almost all of the time. Given his inductive evidence about the regularity of nature, he will probably think that God has chosen to let the universe work according to the laws of nature almost all of the time. What is more, Ken might even have an additional reason to believe in the constancy of the laws, a reason unavailable to the atheist: he might believe that God has good reason to create an regular, orderly world, and for that reason he might well expect that the laws will hold almost all of the time. So it's incorrect that, if one believes an omnipotent God can intervene, then one must have no reason to believe that, for a given law of science L, ' $\mathrm{L}$ holds almost all of the time'. Thus it is false that,

(10b) If an omnipotent God can intervene in events in the known universe, then there is no reason to believe that, for a given law of science L, 'L holds almost all of the time.' 
Can we build an argument for (6) out of Rose's assertion, (10)? If (10b) were true, we could go on to give a good argument for (6) by asserting:

(11b) If we have no reason to believe that, for a given law of science L, 'L holds almost all of the time,' then our ability to do science well will be compromised.

But as we've seen, (10b) is false. We might therefore try:

(10a) If an omnipotent God can intervene in events in the known universe, then there is no reason to believe that 'Necessarily, no law of science ever admits of an exception'.

(11a) If there is no reason to believe that 'Necessarily, no law of science ever admits of an exception', then our ability to do science well will be compromised.

Hence,

(12) If an omnipotent God can intervene in events in the known universe, then our ability to do science well will be compromised,

which is more or less equivalent to (6).

The problem with this argument is that (11a) is entirely unmotivated. Suppose Joan has no reason to believe that all laws of science are necessarily exceptionless. Suppose, in fact, that Joan does not believe that 'Necessarily, no law of science admits of an exception'. How does it follow that Joan's ability to do science well will be compromised? If Joan believes that all laws of science hold almost all of the time, then she can carry out her scientific projects with confidence that the laws hold for the processes she studies. In cases where some experimental result disconfirms one of her theories, she will realize that, say, divine intervention in her laboratory is just exceedingly less likely than a mistake in experimental design, measurement error on her part, or the falsehood of her favoured theory. So Joan will be under no pressure to ignore relevant evidence (or, if she is, it won't be because of her belief in the possibility of occasional divine intervention).

What is more, Joan may hold the common belief, among theists, that God desires that human beings come to understand the nature of the physical world He has created. And if she believes that, then she'll have a reason to think God would not intervene in her (or other people's) experiments. We can see why God might engage in special divine action to perform a miracle which confirms some message God wants confirmed, and we can see why God might engage in special divine action if doing so was necessary to bring about the existence of rational animals. But why would God want to interfere with the increase in human knowledge about His creation? There's reason to think God wouldn't want that. So not only does Joan lack a reason to think God has intervened in a given experiment, she could also have a positive reason to think He has not. All that to say, 
(11a) appears false, and is at any rate unestablished. In the absence of a good argument for (11a), the argument culminating in (12) remains unconvincing.

As another way of supporting (6), we might work with Weinberg's remark that 'the only way that any sort of science can proceed is to assume that there is no divine intervention and to see how far one can get with this assumption' ${ }^{47}$ Here Weinberg appears to be asserting that,

(13) In order for the branch or area of science studying $X$ to proceed, scientists studying $\mathrm{X}$ must employ the working assumption that there is no divine intervention in $\mathrm{X}$.

According to (6), the belief that God may occasionally bring about effects outside the ordinary course of nature is detrimental to the ability to do science well. If (13) is to be used as a premise in an argument for (6), that argument would have to show that the belief that God may occasionally bring about effects outside the ordinary course of nature somehow leads to an inability to employ the working assumption that there is no divine intervention in some particular area X. But a scientist studying $\mathrm{X}$ who holds that God may occasionally bring about effects outside the ordinary course of nature could still realize the utility of operating on the working assumption that there is no divine intervention in X, and could accordingly employ the working assumption that there is no divine intervention in $\mathrm{X}$. Such a scientist would not contravene anything said by (13) to be required for the progress of science. So even if (13) is true, it looks as if it would be of little use in an argument for (6). ${ }^{48}$

Upon inspection, it's not surprising that good arguments for (6) are hard to find. After all, we have independent reason to think (6) is false: Pasteur, Newton, Mendel and many others have both done science well and held the belief that God may occasionally bring about events outside the ordinary course of nature. So there seems to be no necessary connection between belief in the possibility (or actuality) of occasional divine intervention and the ability to do science well. It would indeed be detrimental to the progress of science to adopt the general practice of believing that, if we do not have a convincing naturalistic explanation for $\mathrm{Y}$, then God must have brought about $\mathrm{Y}$ via special divine action. But this practice is quite different from a belief (most likely held on theological grounds) in occasional divine intervention. There appears to be no good reason to think that this belief is harmful to scientific progress.

\section{Conclusion}

It appears, then, that the Gouldian contingency argument fails on at least two different grounds. Contrary to the claims of Gould, Dennett, and others, it is a mistake to think that what we have learned from evolutionary biology somehow shows that human beings are mere accidents of natural history. Nor does what we 


\section{know about the contingency of evolution give us good reason to reject the view that human beings came to be according to a divine providential plan. ${ }^{49}$}

\section{Notes}

1. Speaking of the implications of Darwinian theory and the fact that 'human existence only fills the last micromoment of planetary time', Gould writes: 'For such a limitation [the comparatively limited duration of human existence - MR] has a "plain meaning" - and plain meanings are usually correct .... If we are but a tiny twig on the floridly arborescent bush of life, and if our twig branched off just a geological moment ago, then perhaps we are not a predictable result of an inherently progressive process ... perhaps we are, whatever our glories and accomplishments, a momentary cosmic accident that would never arise again if the tree of life could be replanted from seed and regrown under similar conditions. In fact, I would argue that all these "plain meanings" are true, and that we should revel in the our newfound status and attendant need to construct meanings by and for ourselves'; Stephen Jay Gould Full House: The Spread of Excellence from Plato to Darwin (New York NY: Harmony Books, 1996), 18.

2. Ibid., 216: 'We are glorious accidents of an unpredictable process with no drive to complexity, not the expected results of evolutionary principles that yearn to produce a creature capable of understanding the mode of its own necessary construction.'

3. Idem Wonderful Life: The Burgess Shale and the Nature of History (New York NY: W. W. Norton \& Company, 1989), 14.

4. By 'evolution', I mean the thesis that all life on earth has arisen from one or a few original forms of life via a process of descent with modification, wherein the process of natural selection winnowing random variation was the major mechanism by which the diversity of life arose.

5. Daniel C. Dennett Darwin's Dangerous Idea: Evolution and the Meanings of Life (New York NY: Touchstone, 1996), 59 .

6. Ibid., 59 .

7. Ibid., 56 .

8. Quotations such as these could be multiplied. See, e.g. Richard Dawkins The Blind Watchmaker: Why the Evidence of Evolution Reveals a Universe Without Design (New York NY: W. W. Norton \& Co., 1996), 9: ' $[\mathrm{T}]$ he only watchmaker in nature is the blind forces of physics'; and Douglas Futumya Science on Trial (New York NY: Pantheon, 1983), 12-13: 'Some shrink from the conclusion that the human species was not designed, has no purpose, and is the product of mere mechanical mechanisms - but this seems to be the message of evolution.'

9. On this question, see Peter van Inwagen The Problem of Evil: The Gifford Lectures Delivered in the University of St. Andrews in 2003 (Oxford: Clarendon Press, 2006), 113-134; and my 'The problem of evil and cooperation', in Sarah Coakley and Martin Nowak (eds) Evolution, Games and God: The Principle of Cooperation (Cambridge MA: Harvard University Press), forthcoming.

10. Gould Wonderful Life, 14 .

11. By 'an evolutionary process of the sort we have evidence of', I mean an evolutionary process that began with one or a few very simple forms of life, and in which natural selection was the main mechanism accounting for the origin of species. (1) has 'produced by an evolutionary process of the sort we have evidence of', rather than just 'produced by an evolutionary process', in order to make (1) more plausible. For suppose it read 'The objective probability is very low that human beings would someday be produced by an evolutionary process.' Then it could be objected that there are certain sorts of evolutionary processes (e.g. ones that start with some particular kind of primate) that would have a high probability of leading to the emergence of humans. The insight behind the Gouldian contingency objection is that the sort of evolutionary process that actually occurred was such that $i t$ was not likely to give rise to humans.

12. Genesis $1.26-27$.

13. John of Damascus The Orthodox Faith, bk 2, ch. 12, in Saint John of Damascus: Writings, Frederic H. Chase, Jr (tr.), The Fathers of the Church: A New Translation (Washington DC: Catholic University of America Press, 1958), XXXVII, 235. 
14. Thomas Aquinas Summa Theologiae, I.93.4.

15. Ibid., I.93.6c and ad 3.

16. Gould himself comes close to making this sort of claim: 'let [the tape of life] play again from an identical starting point, and the chance becomes vanishingly small that anything like human intelligence would grace the replay'; Gould Wonderful Life, 14, italics added.

17. This is the argument we get by replacing 'human beings' with 'rational animals' in all the propositions of the original argument.

18. See Simon Conway Morris Life's Solution: Inevitable Humans in a Lonely Universe (Cambridge: Cambridge University Press, 2003), especially chs 8-9, and his earlier The Crucible of Creation: The Burgess Shale and the Rise of Animals (Oxford: Oxford University Press, 1998). Conway Morris is a Professor of Evolutionary Palaeobiology at the University of Cambridge.

19. Idem Life's Solution, 283-284.

20. Ibid., xv.

21. Ibid., xii.

22. So John Maynard Smith. See Conway Morris Life's Solution, xi and xii.

23. Ibid., 162.

24. Ibid., xii.

25. Ibid., ch. 7, especially 151-158.

26. See ibid., chs 8-9.

27. Some may object that God, as the source of all being and all causality, could ensure the occurrence of an indeterministically event (just by willing it). I think this view can be shown to lead to a contradiction; for an argument to this effect, see my 'Providence in an indeterministic world: the chess-master model', forthcoming.

28. If God is prepared to guide evolution in the first place, why use evolution by natural selection at all? On this question, see my 'The problem of evil and cooperation'.

29. The concept of special divine action is best understood by contrast with God's general action of producing and sustaining created things. On the view I have in mind, God has made a world which functions in a regular, orderly way - there is such a thing as the ordinary course of nature. And God is at all times active in sustaining the existence and causal power of created things. But God may occasionally wish to bring about effects, at certain times and for particular reasons, that depart from the ordinary course of nature. Doing so involves special divine action. Cases of special divine action include, but are not exhausted by, (1) cases in which God directly and immediately produces an effect of a sort that would normally be the effect of a created cause; and (2) cases in which God brings it about that a created cause produces an effect beyond its ordinary capacity. If God directly brought about the motion of some material entity, we would have an example of the first category. If God, say, brought it about that an electron repels another negatively charged particle with greater force than it ordinarily would, we would have an example of the second category.

30. Peter Geach Providence and Evil (Cambridge: Cambridge University Press, 1977), 58.

31. There are important differences between the view Geach has in mind with respect to the course of human events and the view I have in mind with respect to the course of pre-human evolution. One concerns divine eternity: Geach denies the classical doctrine that all times, including those future to us, are present to God (see Geach Providence and Evil, 56-57). Although I occasionally use tensed language to refer to God, the view I present is compatible with divine eternity.

32. The chess-master analogy is misleading in several respects. While a chess-master and his or her opponent are on the same ontological level and have the same fundamental kinds of causal powers, God and human beings are radically different. God's sustaining action at every moment is required for any human action whatsoever, and all human causal powers owe their existence to God's causal power. Besides these disanalogies relating to being and causality, there are also important disanalogies relating to knowledge. God, in my own view, is timelessly eternal, so that God eternally knows the outcome of all events in virtue of His knowledge of vision, whereas a human chess-master could not have that sort of knowledge. Still, for all their disanalogies, the two cases are similar in this important respect: just as a chess-master can be assured of victory by virtue of his or her ability to respond successfully to any move his or her opponent might make, so God can be assured of the outcome of an indeterministic evolutionary process by virtue of His ability to respond successfully to any indeterministically produced event that might occur in the course of that process. 
33. There is a great deal of literature on divine action that is relevant to the objections I have in mind. See, inter alia: William Alston, 'God's action in the world', in idem Divine Nature and Human Language: Essays in Philosophical Theology (Ithaca NY: Cornell University Press, 1989), 197-222; Alvin Plantinga 'Divine action in the world (synopsis)', Ratio, 19 (2006), 495-504; Paul Draper 'God, science, and naturalism' in W. J. Wainwright (ed.) The Oxford Handbook of Philosophy of Religion (Oxford: Oxford University Press, 2005), 272-303; the work produced in several volumes by the Divine Action Project, under the auspices of the Vatican Observatory and the Center for Theology and the Natural Sciences at Berkeley, e.g. R. J. Russell, P. Clayton, K. Wegter-McNelly, and J. Polkinghorne (eds) Quantum Mechanics: Scientific Perspectives on Divine Action, V, (Berkeley, CA: Vatican Observatory and the Center for Theology and the Natural Sciences, 2001).

34. The Dwight H. Terry Lectureship Centennial Conference, The Religion and Science Debate: Why Does It Continue?, 14-15 September 2006, Yale University.

35. On the spontaneity of mutations, see S. E. Luria and M. Delbrück 'Mutations of bacteria from virus sensitivity to virus resistance', Genetics, 28 (1943), 491-511.

36. That God has guided evolution.

37. A situation in which we have complete knowledge of the history of natural causes and in which we can see that there are no naturally indeterministically produced events would look to us like a situation in which there is no ontological indeterminacy simpliciter.

38. Thomas Tracy 'Creation, providence, and quantum chance', in Russell, Clayton, Wegter-McNelly, and Polkinghorne Quantum Mechanics, 256.

39. This possibility has been explored by several authors. See Tracy 'Creation, providence, and quantum chance', 256.

40. I should briefly mention an objection that I won't be considering here. It is sometimes suggested that the view I've labelled as the chess-master view of God's providence requires that God violate the laws of nature if $\mathrm{He}$ is to guide the course of evolution. As has been noted by Plantinga and Alston, this assertion seems clearly mistaken (see the works by Plantinga and Alston cited in n. 33). Alston's basic argument hinges on a distinction between two ways a law of nature might be formulated. A law of nature might (a) provide unqualified sufficient conditions for the occurrence of some event, or (b) provide conditions sufficient for the occurrence of some event, subject to some qualifying proviso to the effect that other forces or factors not mentioned in the law are absent. Consider, for example, two possible laws stated in general terms: (L1) If an entity E satisfies conditions $\mathrm{C} 1-\mathrm{Cn}$, then $\mathrm{E}$ will act in way W. (L2) If an entity E satisfies conditions $\mathrm{C} 1-\mathrm{Cn}$, then $\mathrm{E}$ will act in way W, provided that no influences on E not specified in conditions $\mathrm{C} 1-\mathrm{Cn}$ are present. Now, suppose there is an entity E that does satisfy conditions $\mathrm{C}-\mathrm{Cn}$, and suppose that God directly causes $\mathrm{E}$ to act in a way other than way W. This would be a counter-example to, and thus a violation of, (L1), but it would be neither a counter-example to nor a violation of (L2), since God's direct influence on $\mathrm{E}$ is an influence not specified in conditions $\mathrm{C} 1-\mathrm{Cn}$. Special divine action would involve a violation of the first type of law, but not the second. Next, Alston argues, any law which we are justified in accepting would have to be of the second sort, not the first. For this argument, see Alston 'God's action in the world', 212.

41. Michael R. Rose Darwin's Spectre: Evolutionary Biology in the Modern World (Princeton NJ: Princeton University Press, 1998), 205.

42. Steven Weinberg Dreams of a Final Theory (New York NY: Pantheon Books, 1992), 247.

43. Rose Darwin's Spectre, 205.

44. Ibid., 205.

45. While I take on Rose's language of whether 'laws of science' will 'necessarily' remain constant or exceptionless, I do not mean to endorse this language, or any particular theory of the laws of nature. I take up Rose's language simply in order to show that his comments do not add up to a good argument for (6). Also, see n. 40.

46. With appropriate caveats for differences in the very early moments after the Big Bang.

47. Weinberg Dreams of a Final Theory, 247.

48. It is sometimes claimed that the scientific method presupposes that physical reality is a closed causal system. In assessing this claim, we should bear in mind the distinction between what the scientific method requires its practitioners to believe and what it requires its practitioners to adopt as a working assumption. For the reasons given in the paragraph to which this note is appended, it seems clear that the scientific method does not require an actual belief that physical reality is closed. 
49. For their helpful comments on this material, I thank the members of the Evolution and Theology of Cooperation project at Harvard University, especially Philip Clayton and Sarah Coakley; my colleague at the University of St Thomas, Gary Atkinson; and the Editor and two anonymous referees for Religious Studies. I am also grateful to the John Templeton Foundation for financial support during the time in which this paper was written. 